CRITICAL REVIEWS IN FOOD SCIENCE AND NUTRITION

2006; Volume46 (5) Pages 409-421

(c) 2006 CRC Press
Archimer, archive institutionnelle de l'ffremer http://www.ifremer.fr/docelec/

\title{
Trends in postmortem aging in fish: understanding of proteolysis and disorganization of the myofibrillar structure
}

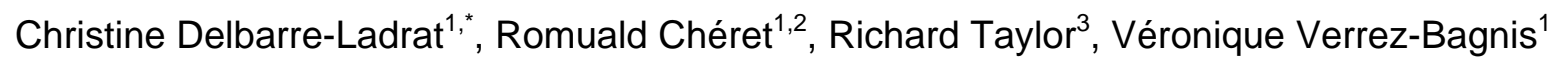

\section{IFREMER, DRV-VP, Rue de l'lle d'Yeu, BP21105, 44311 Nantes Cedex 3, France}

2 ENITIAA, UMR CNRS 6144, GEPEA, Rue de la Géraudière, BP82225, 44332 Nantes Cedex 3, France

3 SRV, INRA, 63122 St Génes-Champanelle, France

*: Corresponding author : cladrat@ifremer.fr

Keywords: fish muscle, postmortem, proteolysis, quality, indicator 


\section{Introduction}

Quality attributes of fish flesh, including food safety, organoleptic features, nutritional quality and aptitude to industrial transformation, influence consumption and acceptability of fish as food. Fish sensorial changes and texture properties are closely linked to freshness. Along with ante mortem muscle biochemistry, postmortem biochemical processes are directly linked to final quality attributes. The understanding of postmortem mechanisms is a prerequisite for an accurate control of the quality of commercialized fish by the identification of objective markers or indicators.

Postmortem tenderization is one of the most important quality attributes of fish muscle. Loss of freshness is due to a complex combination of biochemical, chemical and physical processes, and is followed by muscle spoilage due to microbiological contamination. Autolytic modifications include protease action on proteins and connective tissue, and also fat hydrolysis. Tenderization is enzymatic in nature; physio-chemical conditions ( $\mathrm{pH}$, osmotic pressure) may modulate the proteolytic action of endogenous enzymes.

Our studies have given additional information regarding the proteolytic mechanisms involved in postmortem disorganization of fish muscle by characterizing the myofibrillar components undergoing proteolysis ${ }^{1-3}$ as well as by studying the involved proteases especially calpains $4 ; 5$ and their effects in vitro on myofibrillar proteins ${ }^{6}$. The knowledge of the relationship between this disorganization, loss of freshness, and textural degradation should be improved in order to identify potential freshness indicators, and develop methods to improve quality. The purpose of this paper is to give a broad overview of quality changes in fish and the possible mechanisms responsible.

\section{Effect of cold storage on fish muscle}

\section{Muscle metabolism postmortem}

Immediately after the cessation of the circulation of blood and, consequently, of oxygen supply, the stored carbohydrate glycogen is anaerobically degraded and lactic acid accumulates in muscle ${ }^{7-9}$ resulting in a $\mathrm{pH}$ drop from a value close to 7.4 to 6 in fish, sometimes below ${ }^{10}$. Muscle osmotic pressure increases within hours postmortem ${ }^{11}$, ATP (adenosine triphosphate) decreases ${ }^{7-9}$ and lipids are oxidised. TMAO (trimethylamine oxide) is changed to TMA (trimethylamine) by endogenous enzymes and later by bacteria when microbial activity begins ${ }^{10}$, and nitric oxide and reactive species of oxygen also increase ${ }^{12}$. Mitochondria and sarcoplasmic reticulum deterioration due to $\mathrm{pH}$ fall and osmotic pressure changes results in the release of calcium ions in the cytosol where concentrations can reach $0.2 \mathrm{mM}$ free calcium ${ }^{11}$.

The onset and extent of rigor mortis are biochemically characterized by a total exhaustion of energy-rich compounds. ATP depletion initiates the rigor mortis process ${ }^{13 ; 14}$, and at less than $2 \mu \mathrm{M}$ ATP ${ }^{15}$, actin and myosin form inextensible actomyosin, which causes stiffness of the whole body in rigor mortis. The rigor generally begins one to six hours after death in fish ${ }^{16}$; in particular, it is maximal one day and a half after death for sea bass muscle stored at $\mathrm{O}^{\circ} \mathrm{C}$. This condition usually lasts for a day and then the resolution of rigor mortis makes the muscle less rigid and no longer elastic. Rigor is very dependent on stress before slaughter: control salmon shows mean maximum rigor at about 8 hours postmortem, whereas highly stressed fish can enter rigor as soon as 30 minutes postmortem ${ }^{17-19}$.

Some time after death, an opposing process called tenderization begins within hours postmortem and continues during postmortem storage. Several studies showed that tenderization begins in the early stage of postmortem storage of fish ${ }^{20}$ and mammals ${ }^{21}$. The key structures which are degraded are the cytoskeletal links to sarcomeres and to the plasma 
membrane ${ }^{22-24}$. Several studies suggest that the gradual disintegration of the extracellular matrix structure is also responsible for tenderization of fish ${ }^{25}$. Tenderization rate and extent vary depending on species and other factors. In particular, pelagic fish muscles are more quickly degraded than fish from the deep ocean ${ }^{9}$.

\section{Muscle structure is modified after the death}

Prote in composition in muscle

Muscle is composed mainly of myofibrillar proteins. The myofibrillar content is higher in fish (60-80 \% of the total protein content) than mammals (40\%). The myofibrillar fraction, or structural proteins, accounted for $64 \%$ of the total protein in rainbow trout white muscle, whereas the soluble sarcoplasmic protein comprised $30 \%$ of total protein ${ }^{26}$. Fish sarcoplasmic proteins account for 20-50 \% of the total muscle proteins and are composed mainly of glycolytic enzymes and other enzymes participating in the cell metabolism 27;28. Connective tissue proteins (collagen) constitute 3-10 \% of the proteins in fish muscle.

Lacking the tendinous system connecting muscle bundles to the skeleton as in mammals, fish muscle cells run in parallel and are connected to sheaths of connective tissue (myocommata), which are anchored to the skeleton and the skin ${ }^{29}$. Mammalian and fish skeletal muscles are characterized by the precise organization of the contractile proteins into striated myofibrils resulting from repeating units arranged in series, the sarcomeres (Figure 1). Desmin intermediate filaments occupy a strategic position linking individual myofibrils laterally at their $\mathrm{Z}$ disks and interconnecting sarcomeres to the sarcolemma membrane (the cytoskeleton is reviewed by Greaser ${ }^{30}$ and Small et al ${ }^{31}$ ). An intermediate filament lattice envelops and links all sarcomeres to the membrane cytoskeleton (costamere), mitochondria, nuclei and sarcoplasmic reticulum. Desmin intermediate filaments are essential to maintain the tensile strength and structural integrity of muscle fibers. Dystrophin is a key component of the costameres, the vinculin-rich sub-sarcolemmal transverse cytoskeleton. It is a $400 \mathrm{kDa}$ protein which is bound by its $\mathrm{C}$-terminal to transmembrane proteins and by its $\mathrm{N}$-terminal to $\mathrm{F}$ actin filaments. $\alpha$-actinin is known to be a key component of the vertebrate muscle Z-disk which connects neighboring sarcomeres and possesses a structure strong enough to transmit the tension developed by the interaction of thin and thick filaments of individual sarcomeres. Direct implication of $\alpha$-actinin in the organization and stability of Z-disks in skeletal muscle myofibrils has been well documented ${ }^{32 ; 33}$. Myosin is an asymmetric, hexameric protein of about $500 \mathrm{kDa}$ containing several structural and functional domains. It is assembled into thick filaments, the functional form of myosin in muscle. Polymerized into thin filaments, actin is the second most abundant protein in muscle. The interaction between thin actin filaments and thick myosin filaments generates the force for muscle contraction. Titin (or connectin), the third most abundant protein in the myofibrils, is the largest protein yet discovered (approximately $3000 \mathrm{kDa}$ ). It serves at least two functions in striated muscle cells by providing a template for thick myosin filaments and as an elastic connecting element between thick filaments and the sarcomeric Z-lines ${ }^{34 ; 35}$, binding to $\alpha$-actinin in the $\mathrm{Z}$ line ${ }^{36 ; 37}$. Nebulin, another significant component of skeletal muscle myofibril, is a quite large (approximately $800 \mathrm{kDa}$ ) protein which constitutes inextensible filaments in conjunction with the thin actin filaments. The muscle proteins tropomyosin and troponin are closely involved in the regulation of muscle contraction. Tropomyosin, which is a part of the thin filaments, is a dimeric protein; the distribution of its isoforms in fish muscle has been extensively studied by Heeley et al ${ }^{38}$. Troponin consists of three components, each of which performs specific functions. Troponin $\mathrm{C}$ binds $\mathrm{Ca}^{2+}$, troponin I inhibits the ATPase activity of actomyosin, and troponin $\mathrm{T}$ provides for the binding of troponin to tropomyosin. 
In skeletal muscle, the extracellular matrix or connective tissue is structurally and functionally complex ${ }^{39 ; 40}$. Collagen is the main constituent of this matrix which is responsible for the integrity of myocommata and the mechanical properties of muscle. Connective tissue is composed of the epimysium which envelopes the muscle, the perimysium, surrounding the bundles of myofibers, and the endomysium which surrounds the individual muscle fibers. In teleost fish muscle, there are two main types of collagen, type I and V collagens, with different biochemical characteristics ${ }^{41 ; 42}$.

\section{Observed proteolysis in muscle}

Proteolysis of cytoskeletal components results in myofilament degradation ${ }^{43 ; 44}$. In fish, depending on species, this may include degradation of titin ${ }^{45}$, nebulin ${ }^{46}$, dystrophin ${ }^{47}$, $\alpha$-actinin release ${ }^{48 ; 49}$, myosin proteolysis, and tropomyosin delocalisation ${ }^{46}$. Desmin is degraded in turbot and sardine but not in sea bass ${ }^{2}$ and in croaker ${ }^{43}$. Conversely, in postmortem bovine muscle, desmin is an excellent substrate for calpains and it is largely degraded at $4^{\circ} \mathrm{C}$ during the aging process ${ }^{23 ; 50}$. The costameres which link sarcomeres to the sarcolemma are also degraded within $24 \mathrm{~h}$ postmortem ${ }^{22 ; 47}$. Most of the changes are common among different fish species but they may occur at different rates ${ }^{51}$. In particular, sea bass muscle changes include the detachment of sarcolemma, the degradation of titin and nebulin as well as the release and proteolysis of $\alpha$-actinin from the $\mathrm{Z}$ line and the degradation of dystrophin ${ }^{46-48}$. We found that desmin remained unchanged after a 4 days cold storage in sea bass muscle, but was highly degraded in sardine ${ }^{2}$. A sarcoplasmic $16 \mathrm{kDa}$ protein (identified as nucleoside diphosphate kinase) was also shown to undergo proteolysis upon storage ${ }^{3}$. Tropomyosin was released from the myofibrils; the content of extracted tropomyosin increased with time between 0 and $48 \mathrm{~h}$ in the presence of $5 \mathrm{mM}$ EGTA. In extracts with 5 $\mathrm{mM} \mathrm{Ca}{ }^{2+}$, tropomyosin was observed in lower quantities after $48 \mathrm{~h}^{46}$.

Connective tissue collagen is degraded in fish after death as shown by scanning electron microscopic analysis of muscle as a progressive breakdown of the collagen junctions between the myocommata and the muscle fibers during storage in ice. The structural change in collagen fibrillar network in fish correlates with the postmortem tenderization ${ }^{52}$. Collagen fibrils in the pericellular connective tissue are disorganized and degraded, and space between fibers increases. Bremner ${ }^{41}$, in a review on the role of collagen in fish flesh structure, indicated that this main extracellular matrix component is predominant in determining the textural attributes of the raw flesh. The decrease of type $\mathrm{V}$ collagen content has a correlation with the postmortem softening of fish meat during chilled storage ${ }^{53-55}$. Cleavage of intermolecular collagen cross-links seems to occur during storage of farmed Atlantic salmon on ice ${ }^{56}$. However, some authors reported that there are no significant differences in collagen solubility during storage of Atlantic salmon ${ }^{57}$ and halibut ${ }^{58}$. Several studies have shown that collagen is soluble in fish muscle postmortem, and the solubility relates to texture, season, and water temperature ${ }^{57 ; 59 ; 60}$.

Postmortem muscle structural changes

Fish muscle is organized as tissue blocks of myomeres attached to myocommata. This structure makes the flesh inherently soft, especially when cooking, because fish connective tissue is soluble at low cooking temperatures. However, there is very little structural change in fish myofibrils postmortem, and in fact they are much more stable than mammalian. Beef and sheep structural changes are well characterized ${ }^{23 ; 61 ; 62}$ and show significant breaks in I bands and costameres after 7 days of storage. In marked contrast, fish I bands are almost never broken $1 ; 22 ; 43 ; 44$. As mentioned above the cytoskeletal proteins of fish and mammals are degraded within days postmortem, so it is surprising that fish myofibrils are structurally stable. A possible explanation is that these results are based on electron microscopy of 
carefully handled samples. In fact, when fish ${ }^{63 ; 64}$ and mammalian ${ }^{65 ; 23}$ myofibers are purified and the myofiber breaks quantified, both show extensive breaks postmortem. Therefore, mechanical disruption is needed to demonstrate the fragility of fish myofibers. The myofiber fragmentation index correlates with fish texture.

Both fish ${ }^{22 ; 47}$ and mammals ${ }^{23 ; 62}$ show myofiber to connective tissue (endomysium) detachments within 24h postmortem. Quantification of these breaks demonstrates that they are associated with fish fillet texture, and probably account for much of the early texture changes ${ }^{22}$. As mentioned above the costamere degradation and endomysium detachment is due to calpain activity against cytoskeletal proteins.

The connective tissue of mammals ${ }^{62}$ and fish ${ }^{22}$, especially the endomysium, is very stable postmortem, but it is detached from the myofibers. Endomysium detachment is due to cytoskeletal breaks as mentioned above, but not to degradation of the connective tissue. The endomysium, at least in mammals, is also heat stable. Perimysium shows some weakening by scanning electron microscopy of muscle extracts ${ }^{25}$ but it is rare to see extensive breaks. There are breaks within the myocommata after about 5 days of storage, breaks which are associated with gaping ${ }^{41}$. The myocommata is also mechanically weakened ${ }^{66}$ during storage, and is very heat labile ${ }^{67}$. It is the fragility of the connective tissue which contributes to fillet gaping and long term storage texture changes ${ }^{22}$.

\section{Role of proteases in postmortem autolysis of fish muscle}

Deterioration of fish flesh results from the complex combination of physical, chemical, biochemical and microbial processes. However, the first changes occurring in postmortem fish muscle are due to endogenous enzymes promoting proteolysis of muscle proteins and connective tissue as well as fat hydrolysis. Indeed, the muscle is not significantly contaminated by bacteria at this stage.

\section{Proteases in fish muscle}

Different proteolytic systems exist within the muscular cell: a multicatalytic complex or proteasome, a lysosomal system including aspartic and cysteine acidic cathepsins, the cytosolic calcium dependent calpains, as well as cytoplasmic aminopeptidases, alkaline proteases ${ }^{68}$, and connective tissue hydrolytic enzymes such as elastase and collagenase ${ }^{69}$.

The multicatalytic complex is involved in the degradation of hormones, antigens, transcription factors, and ubiquitin-conjugated or oxydized proteins ${ }^{70}$. The $26 \mathrm{~S}$ proteasome requires ATP for activity and hydrolyses ubiquitin-conjugated proteins. The 20S proteasome, which in fact is also a part of $26 \mathrm{~S}$ proteasome, exists as a latent form possibly activated by different compounds ${ }^{71 ; 72}$. High temperature $\left(60^{\circ} \mathrm{C}\right)$ and SDS (sodium dodecyl sulfate) increase in vitro activity of proteasome from rabbit ${ }^{73}$ and sheep ${ }^{74}$, and both are required for fish proteasome activity in vitro ${ }^{70 ; 75}$.

Cathepsins are acid proteases usually located in organelles called lysosomes and thus are for the most part inactive in living tissue, but become released at sites of injury or upon freezing and thawing of postmortem muscle. Cathepsins can be distinguished by their active site (aspartic, cysteine, serine proteases) as well as by their substrate specificity and inhibitor sensitivity. Lysosomes are known to harbour at least 13 cathepsins ${ }^{76}$. Among them, cathepsins B, D, L, L-like have already been purified from fish. Cathepsins B, D, L and H are the major cathepsins within the fish muscle lysosomes ${ }^{77}$. We have tested cathepsins $\mathrm{B}, \mathrm{L}$ and L-like, $\mathrm{H}$ in sea bass white muscle using fluorescent synthetic substrates. A greater amount of cathepsin L, but a lower level of cathepsin B, have been detected compared to beef muscle. No cathepsin $\mathrm{H}$ was found. Cathepsin $\mathrm{D}$ has also been found in high quantity (unpublished results). 
Calpains are cysteine proteases active at neutral $\mathrm{pH}$ and are dependent upon calcium (calpains have been recently reviewed by Goll ${ }^{78}$ ). Ubiquitous calpains include calpain I or micro $(\mu)$-calpain which requires micromolar calcium concentration for full activity (10 to 50 $\mu \mathrm{M})$ and calpain II or milli(m)-calpain requiring millimolar calcium concentrations (300 $\mu \mathrm{M}$ to $1 \mathrm{mM})^{79}$. A form with intermediary calcium sensitivity co-existing with the two others has also been described in chicken muscle ${ }^{80}$. Calpain-like proteases have been described as atypic calpains (lacking domains involved in calcium activation) and others as tissue-specific such as skeletal muscle specific calpain p94 ${ }^{81 ; 82}$. The discovery of n-calpains (for nano-calpain) in stomach ${ }^{79}$ and in digestive tract ${ }^{83}$ is recent. Braun et al have proposed a classification of calpains based on their activity and regulation ${ }^{84}$. Calpains are heterodimers dissociating in presence of calcium. The small subunit $(30 \mathrm{kDa})$ is common to ubiquitous calpains and the large subunit $(80 \mathrm{kDa})$ is specific to the calpain type and is responsible for catalytic activity 85. Calpains, active at intracellular physiological $\mathrm{pH}$, are highly regulated in vivo. The regulation of calpain activity is complex and not fully understood. The regulation system is based on calcium binding, subunit association, interaction with calpastatin (the endogenous inhibitor specific to calpains) and cellular membranes as well as limited autolysis in the presence of calcium allowing proteolytic activity, but increasing instability ${ }^{86}$. Calcium binding is due to EF Hand structural motifs in the calpain molecule resulting in a conformational switch allowing the alignment of the catalytic amino acid trio Cys, His, Asn ${ }^{87}$. Four properties of calpains are calcium dependent: binding to cellular components such as membranes, calpastatin binding, proteolytic activity and autolysis ${ }^{88}$. However, it is not clear whether autolysis is required and proceeds before substrate proteolysis ${ }^{89 ; 90}$.

We characterized the sea bass white muscle neutral calcium-dependent system in order to determine its features and regulation. Three different calpain-like activities have been detected in postmortem white muscle from sea bass: two similar to m-calpain and one to $\mu$ calpain. They share many biochemical properties with those from terrestrial vertebrates but are differently expressed throughout the year. In particular, the $\mu$-calpain isoform was only detected during the spawning period of sea bass. This could be related to the variation, from season to season, of the extent or the rate of muscle degradation ${ }^{4}$. Geesink et al partially purified calpains from salmon and compared their activities to sheep and beef calpain. Salmon had about as much calpastatin as sheep but 100 -fold lower postmortem calpain activity ${ }^{63}$.

Matrix metalloproteases (MMP) represent a large family of structurally related endopeptidases responsible for connective tissue catabolism. MMPs are able to degrade different types of collagen and cytoskeletal proteins connecting the sarcolemma to the extracellular matrix ${ }^{91}$. They are zinc and calcium-dependent enzymes, classified into four subfamilies: collagenase, gelatinase, stromelysin and membrane type MMP. Bracho and Haard have characterized some metalloprotease activities in rockfish ${ }^{92}$, Stocknes and Rustad in salmon ${ }^{93}$ and Lodemel et al in cod ${ }^{94}$. Saito et al ${ }^{95 ; 96}$ identified a MMP in rainbow trout fibroblasts and subsequently cloned it, expressed it and characterized it.

Reports on other proteolytic activities such as serine proteases, neutral proteases or alkaline proteases from fish muscle are fragmented.

\section{Factors affecting muscle composition}

White muscle from fish constitutes an important protein energetic reserve. Protein content and protease activities may therefore vary during the year due to environment conditions and physiological factors. A substantial normal variation is observed upon seasonal changes in the proximal composition of fish muscle as well as in calpain forms present in sea bass muscle ${ }^{4}$. In particular, protein content is decreased during the spawning period and calpain activity level is increased. Protein mobilisation has also been reported in response to factors such as stress and starvation ${ }^{97}$ or spawning migration in salmon ${ }^{98 ; 99}$. Degradation 
occurs mainly on sarcoplasmic proteins but myofibrillar proteins are not totally spared ${ }^{100}$. Gomez-Guillen and Batista ${ }^{101}$ have also shown that cathepsin D production is increased during spawning periods (April and October) in Sardina pilchardus muscle. This increase is more marked in females and in red muscles. Yamashita and Konagaya have shown extensive increases of cathepsin L activity in spawning salmon ${ }^{102}$ which may be due to increases of phagocytic cells during spawning ${ }^{103}$. Several hormones are known to be able to regulate muscular protein degradation by acting on proteolytic enzymes ${ }^{104}$. This is in particular the case for cathepsin $\mathrm{L}^{105}$ and the calpain/calpastatin system ${ }^{106 ; 107}$.

Modifications of contractile properties and metabolic characteristics which could potentially influence flesh quality have been described in some species ${ }^{108}$. Cellular mechanisms of seasonal adaptations in metabolism are complex and include differential genetic expression, temperature effect on protein synthesis and degradation, as well as modification in the microenvironment of key metabolic enzymes. The synthesis of isozymes specific to low temperatures has also been reported in polyploid species ${ }^{109}$. Haard ${ }^{68}$ also showed that a proteinase from burbot Lota lota exhibits different catalytic features in winter and summer.

Thus, proteins and enzymes, variable within species as well as between species ${ }^{68}$, vary as well with season in muscle and may reflect the variation of the rate of the muscle tenderization ${ }^{4}$.

\section{Contribution of proteases to postmortem autolytic changes}

Until now an understanding of the complex mechanisms responsible for postmortem fish muscle changes has not reached general agreement. In mammals, with most studies being done on cattle, it is clear that most or even all of the meat tenderness is associated with calpain activity ${ }^{21}$. For fishes, of the different intracellular proteolytic systems identified so far, two major pathways were generally distinguished for muscle proteins degradation during postmortem storage: the cathepsins and the calpains. They probably act in a complementary way and in synergy at different levels of myofibrillar protein degradation process. The identification of the exact role of each protease requires the demonstration that the enzyme is active in the postmortem muscle environment (inhibitor activity, enzyme-substrate colocation, activation process) and the identification of their muscular substrates.

Purified proteasome from lobster ${ }^{75}$ and rabbit ${ }^{110}$ hydrolyses myofibrillar proteins in vitro but it requires activation by heat or addition of SDS. Thus, its role in postmortem degradation could be of less importance but it also needs to be further characterized.

A rapid decrease in $\mathrm{pH}$ after death could indicate that lysosomal acidic proteinases may be active if they are liberated from lysosomes to reach the substrate. Cathepsins $\mathrm{D}$ and $\mathrm{L}$ are believed to play a major role in the autolytic degradation due to their wide $\mathrm{pH}$ range of activity while other cathepsins are active at $\mathrm{pH}$ values too low to be of physiological significance. The high cathepsin content in spawning fish ${ }^{102}$ and rapid degradation of postmortem muscle indicates a possible role also existing in normal fish. Also supporting a role for cathepsin is the degradation of connective tissue proteins within days in fish ${ }^{54 ; 111}$; connective tissue proteins are not susceptible to most proteases but are cathepsin substrates.

The second protease system which can degrade connective tissue is the metalloproteases. These proteases are constitutively inactive in mammals and require signal transduction pathway activation. There is a report of their activity in rockfish ${ }^{92}$ but no studies of their role in texture.

Intracellular postmortem calcium increases to about $300 \mu \mathrm{M}$ and favors a key role of calpains in fillet texture. In vivo calpain can be active at physiologic calcium concentrations as low as $0.3 \mu \mathrm{M}$ as evidenced by autolysis and substrate degradation in platelets ${ }^{112}$. But, in vitro they require free calcium levels one hundred times higher than usual physiological 
calcium concentration ${ }^{113}$ - a paradox never explained ${ }^{90}$. Shimada et al ${ }^{114}$ showed that the ultimate sarcoplasmic calcium ion concentration in postmortem muscle of chicken increased to about $200 \mu \mathrm{M}$ which is about 2000 times higher than in resting muscle. This would be sufficient to activate the calpain system. Membrane phospholipids, protein activators, and phosphorylation have also been proposed to allow in vivo activation of calpains at calcium levels lower than those required in vitro ${ }^{85 ; 115 ; 116}$. Moreover, temporary and localized increases in calcium concentration could also allow substrate hydrolysis at these localized sites especially at the plasma membrane or sarcoplasmic reticulum ${ }^{117}$. Other cations such as $\mathrm{Sr}^{2+}$, $\mathrm{Ba}^{2+}$ are also able to activate calpains in vitro ${ }^{5 ; 86}$.

The rise in free calcium in postmortem muscle has been hypothesized to have a role in tenderization through non-enzymatic processes ${ }^{118}$. This controversial theory suggests a direct effect of calcium per se on several muscle components, such as Z-disk weakening, rigor actomyosin complex weakening, titin splitting, nebulin filaments fragmentation and intermediate filaments of desmin breakdown ${ }^{119 ; 120}$. From their results, Shimada et al ${ }^{114}$ concluded that calcium was involved in Z-disks weakening through direct binding with phospholipids. Takahashi et al ${ }^{121}$ also concluded from their studies that there is an effect of calcium alone on Z-disk weakening. But they could not completely exclude the possibility of some limited proteolysis by an "unknown” protease. Later, Geesink et al ${ }^{122}$ contradicted this theory and proposed alternative explanations on the observed rise in sarcoplasmic calcium and its correlation with the Myofibrillar Fragmentation Index and shear force: (i) the rise in free calcium is the result and not the cause of degradations occurring in the muscle, (ii) free calcium activates the calpain system and subsequently affects its degradative efficiency on myofibrillar structure. This evidence together with the known roles of calpain ${ }^{21 ; 78}$, the inhibition of calpain and tenderness ${ }^{123}$, and animal models such as the callipyge sheep ${ }^{124}$, all indicate that the major protease of tenderness in mammals is calpain.

A number of in vitro studies have clearly demonstrated the susceptibility of numerous myofibrillar proteins to proteolysis by calpains and lysosomal proteinases ${ }^{125-129}$. In sea bass muscle, calpain was able to release $\alpha$-actinin and tropomyosin from myofibrils in vitro. Both calpains and cathepsins degrade myosin heavy chain, $\alpha$-actinin and desmin while actin and tropomyosin appear to be sensitive to cathepsins B, D, L. Troponin T was degraded by cathepsins $\mathrm{B}$ and $\mathrm{L}$ with a concomitant appearance of a $30 \mathrm{kDa}$ band ${ }^{130}$. Minor changes of some other myofibrillar or cytosolic proteins were also observed (creatine kinase and other non identified proteins). Discrepancies exist between observed changes in proteins in refrigerated sea bass muscle and in vitro degradation resulting from calpain or cathepsins action (Figure 2). This is in particular the case for myosin, troponin $\mathrm{T}$ and desmin which are not broken down during storage but are sensitive to calpain or cathepsins.

In addition to their key role in postmortem myofibrillar protein changes, calpains have also been involved in a fish muscle postmortem degeneration called burnt tuna ${ }^{131}$.

Some protease inhibitors have been injected in fish muscle to clarify the role of these enzymes in postmortem tenderization. Kubota at al. ${ }^{132}$ showed that EDTA, a bivalent metal ionic chelator, and 1,10 phenanthroline, a specific inhibitor of metalloprotease, suppress tenderization of flounder muscle. Since E64, a cysteine proteinase inhibitor, showed no effect on tenderization (shear force measured), calpains are not involved in the breakdown of extracellular matrix proteins which is suspected to be responsible for the postmortem tenderization of fish muscle during chilled storage. The authors concluded that matrix metalloproteases degrade extracellular matrix components in fish muscle and consequently trigger postmortem tenderization of Japanese flounder. They also proposed that some serine proteinases are responsible for tenderization. An aspartic protease could also be active in their experiments and consequently could be responsible for tenderization. 
Changes in collagen have been attributed to collagenases; they have also been related to the process responsible for gaping phenomenon in which the muscle fibers are gradually disconnected from the myocommata during chilled storage due to collagen fibers breakdown 41;133. Kubota et al ${ }^{134}$ have pointed out the role of matrix metalloproteinases (MMP-9 in this case) in the disintegration of the intramuscular connective tissue that induces the postmortem tenderization of fish muscle. Lødemel and Olsen ${ }^{135}$ have observed both quantitative and qualitative differences in collagenolytic activities in the muscle of different fish species. MMP-like and serine proteinases exist in the muscle of both Atlantic cod and wolffish, while only the former can be detected in the Atlantic salmon. In the same way, Sentandreu et al ${ }^{136}$ in a review on the role of muscle endopeptidases in meat tenderness discussed the role of MMPs in degradation of the different types of collagen together with the cytoskeletal proteins connecting the sarcolemma to the extracellular matrix. Definitive studies which correlate substrate degradation to texture measures have yet to be done.

None of these systems alone can explain all the changes observed postmortem. Synergy between proteases ${ }^{137}$ and other environment factors exists. During rigor mortis, since osmotic pressure is modified, ionic strength increases and may become high enough to weaken the myofibrillar structure, making it more susceptible to proteolysis ${ }^{11}$. Oxidative processes which induce free radicals and nitric oxide formation may make protein components of muscle more susceptible to proteases and weaken the overall myofibrillar structure. Therefore, a synergistic action between free radical species and proteases, or between osmotic pressure and protease have been proposed ${ }^{11}$.

\section{Postmortem storage and quality of fish flesh}

\section{Methods to evaluate fish quality}

Flesh quality is usually defined in terms of appearance, taste, smell, firmness, juiciness, freshness and process characteristics. It may also involve safety aspects. Therefore, flesh quality is a complex set of characters involving intrinsic factors such as texture, chemical composition, colour, fat content and is heavily influenced by extrinsic factors such as feeding regime, diet composition and pre- or post-slaughter handling procedures.

Fish flesh quality, closely linked to the notion of freshness, can be evaluated by four different methods 16;138-140: (i) Sensorial analysis relying on flavour, odour, texture and appearance criteria ${ }^{141}$ : The European Community provides a multilingual guide using three freshness categories (E, A or B) for a common understanding and interpretation of the descriptions for sensory assessment of fish spoilage including the general appearance of eyes, the texture and physical properties of skin and membranes, gills, gut cavity and the discriminating gill odours that underpin freshness grades (www.fao.org/wairdocs/tan/x5995e/x5995e00.htm); (ii) Chemical methods including K factor 142;143;144 , biogenic amines ${ }^{145}$, lipid hydrolysis and oxidation ${ }^{146}$; (iii) Microbial parameters: when the fish dies, the bacteria from skin, gills and intestines may proliferate freely; microbiological data include total counts ${ }^{147}$, bacteria numbers estimated by microscopy, and specific metabolic evaluation (TMA), identification of pathogenic bacteria by immunology or molecular biology ${ }^{148}$; (iv) Physical methods ${ }^{149}$. Use of the Kramer tool with measures perpendicular to muscle fiber orientation can give repeatable mechanical measures ${ }^{19}$. None of these methods is fully satisfactory since they are too subjective, difficult to implement in the industry or not universal enough.

These methods have been used to assess quality changes in sea bass ungutted whole bodies stored in melting ice up to 22 days ${ }^{150}$. Sensorial analysis of skin, outer slime, eyes, gills, odours, using the EC freshness scale gave grade E for up to 3 days, grade A for a further 6 days and grade $\mathrm{B}$ for five days more; after that, it was graded as unfit. This indicated the 
gradual loss of quality. Microbiological analyses (total viable counts, counts of sulphideproducing bacteria) revealed bacterial amounts lower than spoilage levels. Volatile compounds such as TMA increased very slowly during iced storage. Total volatile bases (TVB) including ammonia, trimethylamine, dimethylamine and other volatile amines were significantly increased only after the fish was in an incipient stage of spoilage. $\mathrm{pH}$ did not change significantly during the first half of the storage (6.34-6.41) and increased slightly after day 12 to 6.69 on day 22. This increase was associated with the state of rapid spoilage of the fish. In whole iced sea bass lipid auto-oxydation appears to be a minor spoilage process. Kvalue and derived $\mathrm{k}_{1}$-value have been shown to provide a good indication of loss of freshness in ice stored fish occurring after 4 days in ice.

\section{Prote in indicators of fis $h$ quality}

Ideally, a new indicator must be able to integrate the effects of time and temperature at the same levels as the changes that occur in the fish. It should derive from a good correlation between its evolution and freshness decline or time of storage, should be non-subjective and independent of slaughter conditions and of physiological status of the fish. A universal method should be applicable to all species and easily implemented in industry: evidence of a protein on immunological strips for example.

A rapid method of determining changes in muscle proteins during postmortem storage can be foreseen since some of these proteins have a fast degradation which can indicate early muscle degradation. A correlation between release kinetics of myofibrillar proteins, proteolytic induction, postmortem degradation rate and extent should allow the identification of qualitative markers of fish flesh.

The aim of all our studies on postmortem sea bass changes was to investigate indicators from myofibrillar autolysis mechanism. Proteolysis is a key parameter to investigate the relationship between structure and food characteristics (texture, organoleptic quality). Myofibrillar and connective tissue proteins are the major components contributing to textural features. However, it is generally recognised that myofibrillar components contribution to firmness is more important than connective tissue components even if they are not easily differentiated. Thus, although connective tissue is structurally and biochemically modified, meat firmness is not modified ${ }^{12}$. However, some authors have also shown the contribution in fish muscle of connective tissue to the flesh texture. Taylor et al have shown that initial texture changes occurring within $24 \mathrm{~h}$ of salmon storage are associated with loss of myofiber-to-myofiber attachments, whereas long term texture changes and gaping are associated with myofiber to myoseptum attachments ${ }^{22}$. Touhata et al ${ }^{151}$ hypothesized that the seasonal change in muscle collagen content could possibly contribute to muscle firmness in red sea bream. Thakur et al ${ }^{152}$ demonstrated that the muscle biochemical composition and raw meat texture of cultured yellowtail vary with the anatomical location in the fillet and the season, the breaking strength is then correlated positively with muscle collagen content. In the same way, Bugeon et al ${ }^{153}$ showed that differences in brown trout texture seemed to be dependent on the connective tissue characteristics induced by exercise during rearing.

In beef, different proteins have been identified as potential markers even if validation has not been achieved at an industrial level ${ }^{154}$. Some of these markers are inappropriate to fish such as desmin ${ }^{2}$ but some others may be interesting such as $\alpha$-actinin because of its structural function or appearance as a $30 \mathrm{kDa}$ proteic fragment .

Geesink et al ${ }^{63}$ identified a $31 \mathrm{kDa}$ degradation product in the washed pellet of myofibrils during refrigerated storage of salmon muscle, as well as during the in vitro digestion of myofibrils by calpain. It could be related to the $30 \mathrm{kDa}$ degradation fragment from troponin $T$ found in tenderized mammalian muscles ${ }^{61}$. In our studies, sea bass troponin $\mathrm{T}$ was degraded by the cathepsins $\mathrm{B}$ and $\mathrm{L}$ with a concomitant appearance of a $30 \mathrm{kDa}$ band 
130. Whether it is related to troponin $\mathrm{T}$ breakdown should, however, be assessed with immunological tools. This appearing fragment could be used as an indicator of the extent of proteolysis. An early study reported a $38 \mathrm{kDa}$ degradation product as a trout texture marker ${ }^{155}$. Dystrophin has also been proposed as a marker of postmortem changes in sea bass upon refrigerated storage or to detect the freezing-thawing process ${ }^{47 ; 156}$. In salmon muscle, dystrophin is $100 \%$ degraded within 2 days, at a time that most of the texture changes have occurred, as well as structural changes related to texture ${ }^{22}$. Thus, dystrophin is a possible early freshness marker. $\alpha$-actinin release from myofibrils may also serve as a marker of disorganization in postmortem fish muscle since its release and proteolysis are time- and temperature- dependent, but the rate of release is species dependent ${ }^{48}$. Moreover, protease inhibitors and their target enzymes have been proposed as markers of texture-associated proteolysis of flesh quality. There is extensive and exhaustive evidence that the initial postmortem calpain activity and the amount of its specific inhibitor, calpastatin, correlate with the extent of tenderization in mammalian muscles ${ }^{21}$. Koohmaraie showed that postmortem tenderization was due to disappearance of the calpain inhibitor rather than to an increase in protease activities. However, the rate of meat tenderization is related to the enzyme/inhibitor ratio more than to the calpain content ${ }^{21}$. In particular, the rapid decline in $\mu$-calpain activity, relative to the calpastatin activity, is likely to reduce the degree of tenderization and ultimate tenderness of beef. In sea bass and salmon muscle stored refrigerated, calpain activity decreases with time but calpastatin remains rather constant ${ }^{63 ; 157}$.

In conclusion, postmortem processes, degraded proteins, and accumulating metabolites are so many that no single indicator is sufficient to evaluate sea food quality. Combining indicators and differentiating those that determine loss of freshness from those that detect bacterial spoilage is necessary. The development of reliable methods to assess the freshness of fish as well as the evaluation of quality criteria has been the goal of fish research for many years. Although significant progress has been made to develop rapid and objective methods, more research is needed to verify these methods. Soluble $\alpha$-actinin, $38 \mathrm{kDa}$ or 30 $\mathrm{kDa}$ degradation product assays, for example, may be implemented for measuring the freshness of all types of fish and fishery products. Postmortem aging is a very complex process dependent on many ante mortem and postmortem factors which can explain the difficulty to understand causes and mechanisms and subsequently to identify quality markers. However, it remains necessary to establish useable criteria for fish freshness and spoilage that are practical for the fish industry and reflect the consumer demand for fish freshness. Equally important is for the industry to show an interest in the use of such markers, and to develop quality labels for superior products.

\section{Acknowledgements}

These studies are supported by IFREMER (http://www.ifremer.fr), le Ministère de l'Agriculture et de la Pêche, INRA (http://www.inra.fr), and EU contract SEAFOODPlus (http://www.seafoodplus.org/). 
Figure 1: A schematic diagram of myofibrillar organisation (adapted from Campbell ${ }^{158}$ and Trinick ${ }^{159}$ )

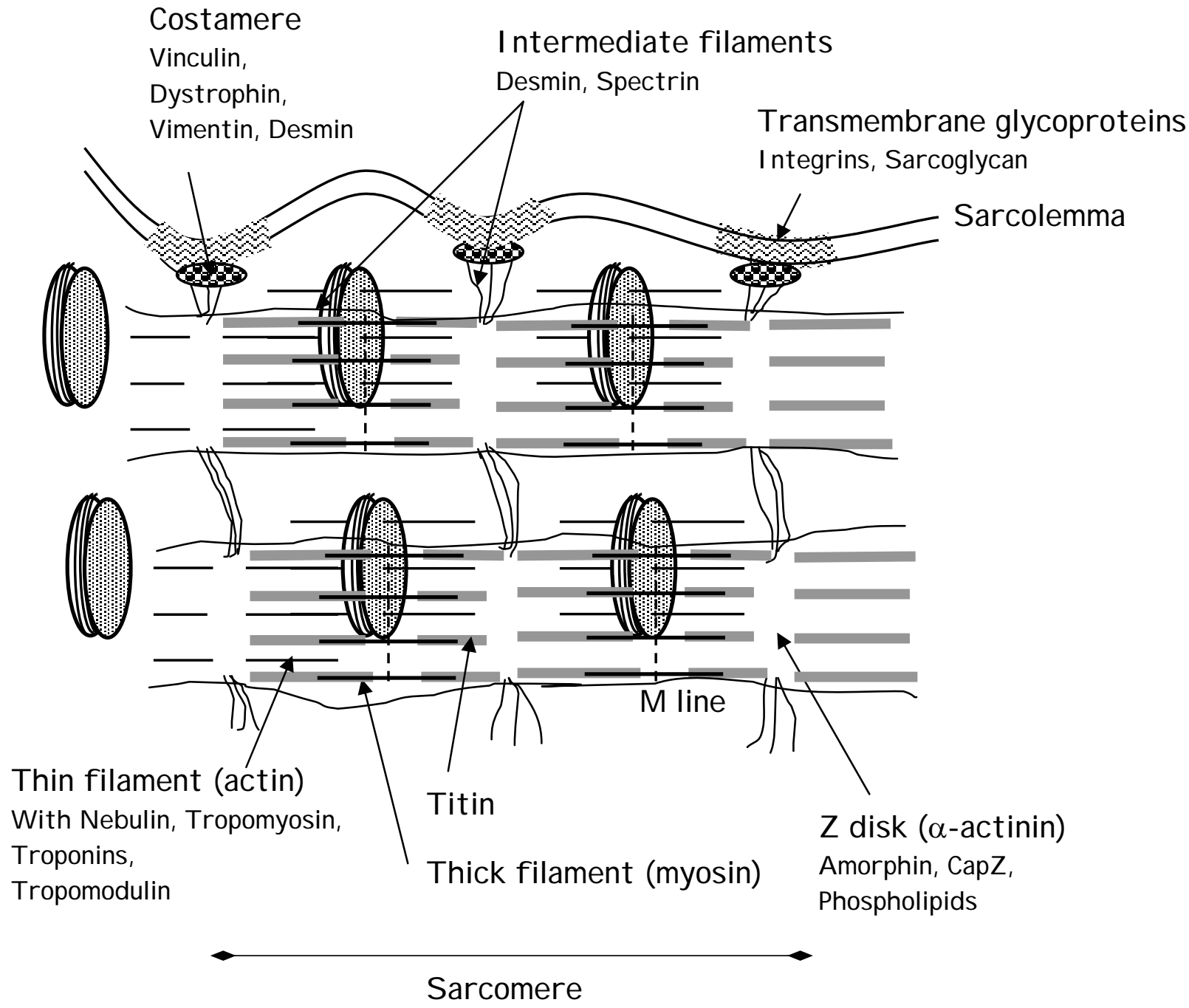


Figure 2: Postmortem events, factors and mechanisms suggested as responsible for flesh degradation and loss of quality during chilled storage of sea bass. Enzymatic factors were suggested in our previous works 6;47;130;137.

Changes encountered post

Suggested factors

Mechanism for loss of quality mortem

\section{1 - Metabolic}

Nucleotides breakdown

Lipid hydrolysis and oxidation

Drop of $\mathrm{pH}$

Increase in osmotic pressure

$\mathrm{Ca}^{2+}$ increase

Increase in nitric oxide and free radicals

\section{2 - Myofibrillar structure}

alpha-actinin release

alpha-actinin proteolysis

Titin degradation

Nebulin proteolysis

Myosin proteolysis (stable in

sea bass)

Tropomyosin delocalisation

Tropomyosin proteolysis

Troponin T proteolysis (stable

in sea bass)

$30 \mathrm{kDa}$ fragment appearance

(not in sea bass)

Actin degradation

\section{3 - Transversal structure}

Desmin degradation in vitro

(stable in sea bass muscle)

4 - Sarcolemma anchorage

Dystrophin degradation
Nucleotide-degrading enzymes

Phospholipases, oxidation status in cell Loss of fresh fish flavour Glycogen degradation and lactic acid accumulation Protein deterioration Increase in osmotic pressure and $\mathrm{pH}$ fall (protein deterioration)

Calpains, cathepsins D and L

Calpains, cathepsins B, D and L

Calcium per se,

Calcium per se,

Calpains, cathepsins B, D and L

Calpains

Cathepsins L

Cathepsins B and $\mathrm{L}$

Cathepsins B and L

Cathepsins L

Calcium per se, calpains, cathepsins B Myofibril destructuration and $\mathrm{L}$

Protein deterioration, enzyme

regulation

Increased susceptibility to

proteolysis

Calcium theory : weakening of

Z-disks, degradation of titin

and nebulin

Increased susceptibility to

proteolysis

$\mathrm{Z}$ disk weakening

$\mathrm{Z}$ disk weakening

Myofibril destructuration

Myofibril destructuration

Myofibril destructuration

Myofibril destructuration

Calpains
Costamere degradation

Intermediate filament and myofibril destructuration 
Reference list

(1) Papa, I., Alvarez, C., Verrez-Bagnis, V., Fleurence, J., and Benyamin, Y., Evidence for time dependent alpha-actinin delocalisation and proteolysis from post mortem fish white muscle (Dicentrarchus labrax and Salmo trutta). In : Luten J.B., Borresen T. and Oehlenschläger J. Eds. Seafood from producer to consumer, integrated approach to quality. Elsevier Science, 1997, 247-252.

(2) Verrez-Bagnis, V., Noël, J., Sauterau, C., and Fleurence, J., Desmin degradation in postmortem fish muscle. J. Food Sci., 1999; 64[2]: 240-242.

(3) Verrez-Bagnis, V., Ladrat, C., Morzel, M., Noël, J., and Fleurence, J., Protein changes in postmortem sea bass ( Dicentrarchus labrax) muscle monitored by one- and twodimensional gel electrophoresis. Electrophoresis, 2001; 22: 1539-1544.

(4) Ladrat, C., Chaplet, M., Verrez-Bagnis, V., Noël, J., and Fleurence, J., Neutral calcium-activated proteases from European sea bass (Dicentrarchus labrax L.) muscle : polymorphism and biochemistry studies. Comp. Biochem. Physiol., 2000; 125B:8395.

(5) Ladrat, C., Verrez-Bagnis, V., Noël, J., and Fleurence, J., Milli-calpain from sea bass (Dicentrarchus Labrax) white muscle : purification, characterization of its activity and activation in vitro. Mar. Biotechnol., 2002; 4[1]:51-62.

(6) Verrez-Bagnis, V., Ladrat, C., Noelle, J., and Fleurence, J., In vitro proteolysis of european sea bass (Dicentrarchus labrax) myofibrillar and sarcoplasmic proteins by an endogenous m-calpain. J. Sci Food Agric., 2002; 82:1256-1262.

(7) Iwamoto, M., Yamanaka, H., Abe, H., Ushio, H., Watabe, S., and Hashimoto, K., ATP and creatine phosphate breakdown in spliced plaice muscle during storage, and activities of some enzymes involved. J. Food Sci., 1988; 53:1662-1665.

(8) Nazir, D. J. and Magar, N. G., Biochemical changes in fish muscle during rigor mortis. J. Food Sci., 1963; 28[1]:1-7.

(9) Watabe, S., Ushio, H., Iwamoto, M., Kamal, M., Ioka, H., and Hashimoto, K., Rigormortis progress of sardine and mackerel in association with ATP degradation and lactate accumulation. Nippon Suisan Gakkaishi, 1989; 55[10]:1833-1839.

(10) Church, N., MAP fish and crustaceans - sensory enhancement. Food Sci. Technol. Today, 1998; 12[2]:73-83.

(11) Mestre Prates, J., Factors and mechanisms responsible for meat ageing. Revue Med. Vet., 2002 ; 153[7] :499-506.

(12) Harper, G. S., Trends in skeletal muscle biology and the understanding of toughness in beef. Aust. J. Agric. Res., 1999; 50[7]:1105-1129.

(13) Bate-Smith, E. and Bendall, J., Rigor mortis and adenosine triphosphate. J. Physiol., 1947; 106:177-185.

(14) Jeacocke, R., The kinetics of rigor onset in beef muscle fibres. Meat Sci., 1984; $11[4]: 237-251$. 
(15) Reedy, M. and Holmes, K., Induced changes in orientation of the cross-bridges of glycerinated insect flight muscle. Nature, 1965; 207:1276-1280.

(16) Watanabe, E. and Turner, A. P. F., Biosensors for the quality control of fish meat. Agro-Food-Ind. Hi-Tech, 1993; March/April:1-16.

(17) Jerret, A. and Holland, A., Rigor tension development in excised rested, partially exercised, and exhausted Chinook salmon white muscle. J. Food Sci., 1998; 63:48-52.

(18) Sigholt, T., Erikson, U., Rustad, T., Johansen, S., Nordtvedt, T., and Seland, A., Handling stress and storage temperature affect meat quality of farmed-raised Atlantic salmon (Salmo salar). J. Food Sci., 1997; 62:898-905.

(19) Skjervold, P., Fjaera, S., Ostby, P., and Einen, O., Live chilling and crowding in Atlantic salmon before slaughter. Aquaculture, 2001; 192:265-280.

(20) Ando, M., Toyohara, H., Shimizu, Y., and Sakaguchi, M., Post-mortem tenderization of fish muscle proceeds independently of resolution of rigor mortis. Nippon Suisan Gakkaishi, 1991; 57[6]:1165-1169.

(21) Koohmaraie, M., Biochemical factors regulating the toughening and tenderization process of meat. Meat Sci., 1996; 43[S]:193-201.

(22) Taylor, R., Fjaera, S., and Skjervold, P., Salmon fillet texture is determined by myofiber-myofiber and myofiber-myocommata attachment. J. Food Sci., 2002, 67[6], 2067-2071.

(23) Taylor, R. G., Geesink, G. H., Thompson, V. F., Koohmaraie, M., and Goll, D. E., Is Z-disk degradation responsible for postmortem tenderization ? J. Anim. Sci., 1995; 73:1351-1367.

(24) Steen, D., Claeys, E., Uytterhaegen, L., De Smet, S., and Demeyer, D., Early postmortem conditions and the calpain/calpastatin system in relation to tenderness of double-muscled beef. Meat Sci., 1997; 45[3]:307-319.

(25) Ando, M., Toyohara, H., Shimizu, Y., and Sakaguchi, M., Post-mortem tenderization of fish muscle due to weakening of pericellular connective tissue. Nippon Suisan Gakkaishi, 1993; 59[6]:1073-1076.

(26) Fauconneau, B., Gray, C., and Houlihan, D. F., Assessment of individual protein turnover in three muscle types of rainbow trout. Comp. Biochem. Physiol., 1995; 111B[1]:45-51.

(27) Nakagawa, T., Watabe, S., and Hashimoto, K., Identification of three major components in fish sarcoplasmic proteins. Nippon Suisan Gakkaishi, 1988; 54[6]:9991004.

(28) Nakagawa, T., Watabe, S., and Hashimoto, K., Electrophoretic analysis of sarcoplasmic proteins from fish muscle on polyacrylamide gels. Nippon Suisan Gakkaishi, 1988; 54[6]:993-998.

(29) Huss, H., La qualité et son évolution dans le poisson frais. In : FAO Document 
technique sur les pęches. N³48. Rome, FAO, 1999, 198 p.

(30) Greaser, M., An overview of the muscle cell cytoskeleton. Proc. Recip. Meat Conf., $1991 ; 44: 1-5$.

(31) Small, J., Furst, D., and Thornell, L., The cytoskeletal lattice of muscle cells. Eur. J. Biochem., 1992; 208:559-572.

(32) Goll, D. E., Dayton, W. R., Singh, I., and Robson, R. M., Studies of the $\alpha$-actinin/actin interaction in the Z-disk by using calpain. J. Biol. Chem., 1991; 266[13]:8501-8510.

(33) Vigoreaux, J. O., The muscle Z band: lessons in stress management. J. Muscle Res. Cell Motility, 1994; 15:237-255.

(34) Koretz, J., Irving, T., and Wang, K., Filamentous aggregates of native titin and binding of C-protein and AMP-deaminase. Arch. Biochem. Biophys., 1993; 304(2):305-309.

(35) Robson, R., Myofibrillar and cytoskeletal structures and proteins in mature skeletal muscle cells. In: Ouali, A., Smulders, F., Demyer, D. Eds. Workshop on Expression, Regulation and Role of Proteinases in Muscle Development and Meat Quality, Nijmegem, The Netherlands: Audet Tejdschriften bv, 1995.

(36) Joseph, C., Stier, G., O'Brien, R., Politou, A. S., Atkinson, R.A., Bianco, A., Ladbury, J. E., Martin, S. R., and Pastore, A., A structural characterization of the interactions between titin Z-repeats and the alpha-actinin C-terminal domain. Biochem., 2001; 40:4957-4965.

(37) Wang, S., and Jeng, C., Interaction between titin and $\alpha$-actinin. Biomed. Res., 1992; 13:197-202.

(38) Heeley, D. H., and Hong, C., Isolation and characterization of tropomyosin from fish muscle, Comp. Biochem. Physiol., 1994; 108B(1):95-106.

(39) McCormick, R., The flexibility of the collagen compartment of muscle. Meat Sci., 1994; 36:79-91.

(40) Purslow, P., The intramuscular connective tissue matrix and cell/matrix interactions in relation to meat toughness. 45th ICoMST Proc., 1999; 210-219.

(41) Bremner, H. A., Fish flesh structure and the role of collagen - its post-mortem aspects and implications for fish processing. In: Huss H.H. et al. Eds. Quality Assurance in the Fish Industry. Elsevier Science, 1992; 39-62.

(42) Sato, K., Yoshinaka, R., Itoh, Y., and Sato, M., Molecular species of collagen in the intramuscular connective tissue of fish. Comp. Biochem. Physiol., 1989; 92B:87-91.

(43) Busconi, L., Folco, E. J., Martone, C. B., and Sanchez, J. J., Postmortem changes in cytoskeletal elements of fish muscle. J. Food Biochem., 1989; 13:443-451.

(44) Ofstad, R., Egelendsdal, B., Kidman, S., Myklebust, R., Olsen, R. L., and Hermansson, A.-M., Liquid loss as effected by post mortem ultrastructural changes in 
fish muscle : cod (Gadus morhua L) and salmon (Salmo salar). J. Sci. Food Agric., 1996; 71:301-312.

(45) Seki, N., and Watanabe, T., Connectin content and its port-mortem changes in fish muscle. J. Biochem., 1984; 95:1161-1167.

(46) Astier, C., Labbe, J.-P., Roustan, C., and Benyamin, Y., Sarcomeric disorganization in post-mortem fish muscles. Comp. Biochem. Physiol., 1991; 100B[3]:459-465.

(47) Papa, I., Taylor, R. G., Astier, C., Ventre, F., Lebart, M. C., Roustan, C., Ouali, A., and Benyamin, Y., Dystrophin cleavage and sarcolemma detachment are early post mortem changes on bass (Dicentrarchus labrax) white muscle. J. Food Sci., 1997; 62[5]:917-921.

(48) Papa, I., Alvarez, C., Verrez-Bagnis, V., Fleurence, J., and Benyamin, Y., Post mortem release of fish white muscle $\alpha$-actinin as a marker of disorganisation. J. Sci. Food Agric., 1996; 72[1]:63-70.

(49) Tsuchiya, H., and Seki, N., Action of calpain on $\alpha$-actinin within and isolated from carp myofibrils. Nippon Suisan Gakkaishi, 1991; 57[6]:1133-1139.

(50) Hwan, S.-F., and Bandman, E., Studies of desmin and $\alpha$-actinin degradation in bovine semitendinosus muscle, J. Food Sci., 1989; 54 (6):1426-1430.

(51) Ingolfsdottir, S., Post mortem changes in fish muscle proteins. Structural changes. In: Olafsdottir, G., Luten, J., Dalgaard, P., Careche, M. Verrez-Bagnis, V., Martinsdottir, E., Heia, K., Eds, Methods to determine the freshness of fish in research and industry. Proceedings of the Final Meeting of the Concerted Action "Evaluation of Fish Freshness" AIRCT94 2283. Nantes. International Institute of Refrigeration. 1997; 198203.

(52) Ando, M., Yoshimoto, Y., Inabu, K., Nakagawa, T., and Makinodan, Y., Post-mortem change of three-dimensional structure of collagen fibrillar network in fish muscle pericellular connective tissues corresponding to post-mortem tenderization, Fisheries Sci., 1995, 61 (2), 327-330.

(53) Ando, M., Nishiyabu, A., Tsukamasa, Y., and Makinodan, Y., Post mortem softening of fish muscle during chilled storage as affected by bleeding. J. Food Sci., 1999; 64[3]:423-428.

(54) Sato, K., Ando, M., Kubota, S., Origasa, K., Kawase, H., Toyohara, H., Sakaguchi, M., Nakagawa, T., Makinodan, Y., Ohtsuki, K., and Kawabata, M., Involvement of type $\mathrm{V}$ collagen in softening of fish muscle during short-term chilled storage. J. Agric. Food Chem., 1997; 45:343-348.

(55) Shigemura, Y., Ando, M., Tsukamasa, Y., Makinodan, Y., and Kawai, T., Correlation of type $\mathrm{V}$ collagen content with post-mortem softening of fish meat during chilled storage. Fisheries Sci., 2003; 69[4]:842-848.

(56) Eckhoff, K., Aidos, I., Hemre, G., and Lie, O., Collagen content in farmed Atlantic salmon (Salmo salar, L.) and subsequent changes in solubility during storage on ice. Food Chem., 1998; 62[2]:197-200. 
(57) Aidos, I., Lie, Ø. L., and Espe, M., Collagen content in farmed Atlantic salmon (Salmo salar L.). J. Agric. Food Chem., 1999; 47:1440-1444.

(58) Olsson, G., Ofstad, R., Lodemel, J., and Olsen, R., Changes in water-holding capacity of halibut muscle during cold storage. Lebensm-Wiss. Technol., 2003; 36[8]:771-778.

(59) Montero, P., and Borderias, J., Distribution and hardness of muscle connective tissue in hake (Merluccius merluccius L.) and trout (Salmo irideus Gibb). Z. Lebensm. Unters. F., 1990; 189:530-533.

(60) Sato, K., Ohashi, C., Ohtsuki, K., and Kawabata, M., Type V collagen in trout (Salmo gairdneri) muscle and its solubility change during chilled storage of muscle. J. Agric. Food Chem., 1991; 39:1222-1225.

(61) Ho, C. Y., Stromer, M. H. and Robson, R. M., Identification of the 30kDa polypeptide in post mortem skeletal muscle as a degradation product of troponin-T. Biochimie, 1994; 76:369-375.

(62) Taylor, R. G. and Koohmaraie, M., Effects of postmortem storage on the ultrastructure of the endomysium and myofibrils in normal and callipyge longissimus. J. Anim. Sci., 1998; 76[11]:2811-2817.

(63) Geesink, G., Morton, J., Kent, M. and Bickerstaffe, R., Partial purification and characterization of Chinook salmon (Oncorhynchus tshawytscha) calpains and an evaluation of their role in postmortem proteolysis. J. Food Sci., 2000; 65[8 ]:13181324.

(64) Tsuchiya, H., Kita, S., and Seki, N. Post-mortem changes in a-actinin and connectin in carp and rainbow trout muscle. Nippon Suisan Gakkaishi, 1992; 58:793-798.

(65) Olson, D. G., Parrish, F. C. and Stromer, M. H., Myofibril fragmentation and shear resistance of three bovine muscles during postmortem storage. J. Food Sci., 1976; 41: 1036-1041.

(66) Love, R., Lavety, J., and Garcia, N., The connective tissues of fish VI. Mechanical studies on isolated myocommata. J. Food Technol., 1972; 7:291-301.

(67) Yamaguchi, K., Lavety, J., and Love, R., The connective tissues of fish VIII. Comparative studies on hake, cod and catfish collagens, J. Food Technol., 1976; 11:389-399.

(68) Haard, N. F., Enzymes from food myosystems. J. Muscle Foods, 1990; 1:293-338.

(69) Blanchard, P. J. and Mantle, D., Comparison of proteolytic enzyme levels in chicken, pig, lamb and rabbit muscle at point of slaughter : role in meat tenderisation post mortem. J. Sci. Food Agric., 1996; 71:83-91.

(70) Dahlmann, B. and Kuehn, L., The 20S/26S proteasomal pathway of protein degradation in muscle tissue. Molec. Biol. Reports, 1995; 21:57-62.

(71) Attaix, D., Aurousseau, E., Combaret, L., Kee, A., Larbaud, D., Rallière, C., Souweine, B., Taillander, D., and Tilignac, T., Ubiquitin-proteasome-dependent 
proteolysis in skeletal muscle. Reprod. Nutr. Dev., 1998; 38:153-165.

(72) Avila, J. L., Proteasomes : multicatalytic proteinase complexes. Interciencia, 1997; 22[2]:51-59.

(73) Otsuka, Y., Homma, N., Shiga, K., Ushiki, J., Ikeuchi, Y., and Suzuki, A., Purification and properties of rabbit muscle proteasome, and its effect on myofibrillar structure. Meat Sci., 1998; 49[4]:365-378.

(74) Koohmaraie, M., Ovine skeletal muscle multicatalytic proteinase complex (proteasome) : purification, characterization, and comparison of its effects on myofibrils with $\mu$-calpains. J. Anim. Sci., 1992; 70:3697-3708.

(75) Mykles, D. L. and Haire, M. F., Branched-chain-amino-acid-preferring peptidase activity of the lobster multicatalytic proteinase (proteasome) and the degradation of myofibrillar proteins. Biochem. J., 1995; 306:285-291.

(76) Kolodziejska, I. and Sikorski, Z. E., Muscle cathepsins of marine fish and invertebrates. Polish J. Food Nutr. Sci., 1995; 4[45]:3-10.

(77) Aoki, T., Yamashita, T., and Ueno, R., Distribution of cathepsins in red and white muscles among fish species. Fisheries Sci., 2000; 66[4]:776-782.

(78) Goll, D., Thompson, V., Li, H., Wei, W., and Cong, J., The calpain system. Physiologic. Rev., 2003; 83:731-801.

(79) Molinari, M. and Carafoli, E., Calpain : a cytosolic proteinase active at the membranes. J. Membr. Biol., 1997; 156:1-8.

(80) Sorimachi, H., Ishiura, S., and Suzuki, K., Structure and physiological function of calpains. Biochem. J., 1997; 328:721-732.

(81) Sorimachi, H., Imajoh-Ohmi, S., Emori, Y., Kawasaki, H., Ohno, S., Minami, Y., and Suzuki, K., Molecular cloning of a novel mammalian calcium-dependent protease distinct from both $\mathrm{m}$ - and $\mu$-types. Specific expression of the mRNA in skeletal muscle. J. Biol. Chem., 1989; 264[33]:20106-20111.

(82) Kinbara, K., Ishiura, S., Tomioka, S., Sorimachi, H., Jeong, S. Y., Amano, S., Kawasaki, H., Kolmerer, B., Kimura, S., Labeit, S., and Suzuki, K., Purification of native p94, a muscle specific calpain, and characterization of its autolysis. Biochem. J., 1998; 335[Part 3]:589-596.

(83) Lee, H. J., Tomioka, S., Kinbara, K., Masumoto, H., Jeong, S. Y., Sorimachi, H., Ishiura, S., and Suzuki, K., Characterization of a human digestive tract specific calpain, nCL 4, expressed in the baculovirus system. Arch. Biochem. Biophys., 1999; 362[1]:22-31.

(84) Braun, C., Engel, M., Theisinger, B., Welter, C., and Seifert, M., CAPN 8: Isolation of a new mouse calpain isoenzyme. Biochem. Biophys. Res. Commun., 1999; 260[3]:671675.

(85) Suzuki, K. and Ohno, S., Calcium activated neutral protease - Structure-function 
relationship and funtional implications -. Cell Struct. Funct., 1990; 15:1-6.

(86) Croall, D. E. and Demartino, G. N., Calcium-activated neutral protease (calpain) system : structure, function, and regulation. Physiologic. Rev., 1991; 71[3]:813-847.

(87) Hosfield, C. M., Elce, J. S., Davies, P. L., and Jia, Z. C., Crystal structure of calpain reveals the structural basis for $\mathrm{Ca} 2+$ dependent protease activity and a novel mode of enzyme activation. EMBO J., 1999; 18[24]:6880-6889.

(88) Goll, D. E., Thompson, V. F., Taylor, R. G., and Zalewska, T., Is calpain activity regulated by membranes and autolysis or by calcium and calpastatin ? BioEssays, 1992; 14[8]:549-555.

(89) Carafoli, E. and Molinari, M., Calpain: A protease in search of a function? Biochem. Biophys. Res. Commun., 1998; 247[2]:193-203.

(90) Johnson, G. V. W. and Guttmann, R. P., Calpains : intact and active. BioEssays, 1997; 19[11]:1011-1018.

(91) Birkedal-Hansen, H., Moore, W., Bodden, M., Windsor, L., Birkedal-Hansen, B., DeCarlo, A., and Engler, J., Matrix metalloproteinases: a review. Crit. Rev. Oral Biol. Med., 1993; 4:197-250.

(92) Bracho, G., and Haard, N., Identification of two matrix metalloproteinases in the skeletal muscle of pacific rockfish (Sebastes sp.). J. Food Biochem., 1995; 19:299319.

(93) Stoknes, I. and Rustad, T., Proteolytic activity in muscle from Atlantic salmon (Salmo salar). J. Food Sci., 1995; 60[4]:711-714.

(94) Lodemel, J., Maehre, H., Winberg, J. and Olsen, R., Tissue distribution, inhibition and activation of gelatinolytic activities in Atlantic cod (Gadus morhua). Comp. Biochem. Physiol., 2004; 137B: 363-371.

(95) Saito, M., Sato, K., Kunisaki, N., and Kimura, S., Characterization of a rainbow trout matrix metalloproteinase capable of degrading type I collagen. Eur. J. Biochem., 2000; 267[23]:6943-6950.

(96) Saito, M., Kunisaki, N., Urano, N., and Kimura, S., Characterization of cDNA clone encoding the matrix metalloproteinase 2 from rain bow trout fibroblast. Fisheries Sci., 2000; 66:334-342.

(97) Gomez Guillen, M. C., Montero, P., Hurtado, O., and Borderias, A., J. Biological characteristics affect the quality of farmed Atlantic salmon and smoked muscle. $J$. Food Sci., 2000; 65[1]:53-60.

(98) Ando, S., Hatano, M., and Zama, K., Protein degradation and protease activity of chum salmon (Oncorhynchus keta) muscle during spawning migration. Fish Physiol. Biochem., 1986; 1[1]:17-26.

(99) Ando, S., Hatano, M., and Zama, K. Deterioration of chum salmon (Oncorhynchus keta) muscle during spawning migration -I. Changes in proximate composition of 
chum salmon muscle during spawning migration. Comp. Biochem. Physiol., 1985; 80B[2]:303-307.

(100) Beaulieu, M. A. and Guderley, H., Changes in qualitative composition of white muscle with nutritional status of Atlantic cod, Gadus morhua. Comp. Biochem. Physiol., 1998; 121A[2 ]:135-141.

(101) Gomez-Guillen, M. C. and Batista, I., Seasonal changes and preliminary characterization of cathepsin D-like activity in sardine (Sardina pilchardus) muscle. Int. J. Food Sci. Technol., 1997; 32:255-260.

(102) Yamashita, M. and Konagaya, S., High activities of cathepsins B, D, H and L in the white muscle of chum salmon in spawning migration. Comp. Biochem. Physiol., 1990; 95B[1]:149-152.

(103) Yamashita, M. and Konagaya, S., Immunohistochemical localization of cathepsins B and $\mathrm{L}$ in the white muscle of chum salmon (Oncorhynchus keta) in spawning migration: probable participation of phagocytes rich in cathepsins in extensive muscle softening of the mature salmon. J. Agric. Food Chem., 1991; 39:1402-1405.

(104) Nakashima, K., Ohtsuka, A., and Hayashi, K., Effects of thyroid hormones on myofibrillar proteolysis and activities of calpain, proteasome, and cathepsin in primary cultured chick muscle cells. J. Nutr. Sci. Vitaminol., 1998; 44[6]:799-807.

(105) Toyohara, H., Ito, K., Hori, N., Touhata, K., Kinoshita, M., Kubota, S., Sato, K., Ohtsuki, K., and Sakaguchi, M., Effect of steroid hormone administration on the breakdown of muscle proteins in ayu. Fisheries Sci., 1998; 64[3]:419-422.

(106) Luno, M., Beltran, J. A., Jaime, I., and Roncales, P., Textural assessment of clenbuterol treatment in beef. Meat Sci., 1999; 51[4]:297-303.

(107) Hayashi, K., Tada, O., Higuchi, K., and Ohtsuka, A., Effects of corticosterone on connectin content and protein breakdown in rat skeletal muscle. Biosci., Biotechnol., Biochem., 2000; 64[12]:2686-2688.

(108) Johnston, I. A., Muscle development and growth : potential implications for flesh quality in fish. Aquaculture, 1999; 177:99-115.

(109) Johnston, I. A., Physiology of muscle in hatchery raised fish. Comp. Biochem. Physiol., 1982; 73B[1]:105-124.

(110) Matsuishi, M. and Okitani, A., Proteasome from rabbit skeletal muscle : some properties and effects on muscle proteins. Meat Sci., 1997; 45[4]:451-462.

(111) Eggen, K., and Ekholt, W., Degradation of decorin in bovine M. Semimembranosus during postmortem storage. 41st ICoMST Proc., 1995; 662-663.

(112) Fox, J., Taylor, R., Taffarel, M., Boyles, J., and Goll, D., Evidence that activation of platelet calpain is induced as a consequence of binding of adhesive ligand to the integrin glycoprotein IIbIIIa. J. Cell Biol., 1993; 120:1501-1507.

(113) Goll, D. E., Kleese, W. C., Kumamoto, T., Cong, J., and Szpacenko, A., In search of 
the regulation and function of the $\mathrm{Ca}^{2+}$-dependent proteinases (calpains). In: Katnuma N., Kominami E. Eds., Intracellular Proteolysis, Mechanisms and Regulation. Tokyo: Japanese Scientific Societies Press, 1989; 82-91.

(114) Shimada, K., Ahn, D. H., and Takahashi, K., Liberation of phospholipids from Z-disks of chicken skeletal muscle myofibrils by $0.1 \mathrm{mM}$ calcium ions : weakening mechanism for Z-disks during post-mortem aging of meat. Biosci., Biotechnol., Biochem., 1998; 62[5]:919-926.

(115) Baki, A., Tompa, P., Alexa, A., Molnar, O., and Friedrich, P., Autolysis parallels activation of $\mu$-calpain. Biochem. J., 1996; 318:897-901.

(116) Johnson, P., Calpains (intracellular calcium-activated cysteine proteinases) : structureactivity relationships and involvement in normal and abnormal cellular metabolism. Int. J. Biochem., 1990; 22[8]:811-822.

(117) Mellgren, R. L., Calcium-dependent proteases : an enzyme system active at cellular membranes ? FASEB J., 1987; 1:110-115.

(118) Takahashi, K., Non-enzymatic weakening of myofibrillar structures during conditioning of meat : calcium ions at $0.1 \mathrm{mM}$ and their effect on meat tenderization. Biochimie, 1992; 74:247-250.

(119) Takahashi, K., Structural weakening of skeletal muscle tissue during post-mortem ageing of meat : the non-enzymatic mechanism of meat tenderization. Meat Sci., 1996; 43[S]:S67-S80.

(120) Tatsumi, R. and Takahashi, K., Calcium-induced fragmentation of skeletal muscle nebulin filaments. J. Biochem., 1992; 112:775-779.

(121) Takahashi, K., Kim, O. H., and Yano, K., Calcium-induced weakening of Z-disks in postmortem skeletal muscle. J. Biochem., 1987; 101[3]:767-773.

(122) Geesink, G., Taylor, R., Bekhit, A., and Bickerstaffe, R., Evidence against the nonenzymatic calcium theory of tenderization. Meat Sci., 2001; 59[4]:417-422.

(123) Koohmaraie, M., The role of $\mathrm{Ca}^{2+}$-dependent proteases (calpains) in post mortem proteolysis and meat tenderness. Biochimie, 1992; 74:239-245.

(124) Koohmaraie, M., Shackelford, S., Wheeler, T., Lonergan, S., Doumit, M., A muscle hypertrophy condition in lamb (Callipyge): characterization of effects on muscle growth and meat quality traits. J. Anim. Sci., 1995; 73[12]:3596-3606.

(125) Aoki, T. and Ueno, R., Involvement of cathepsins B and L in the post-mortem autolysis of mackerel muscle. Food Res. Int., 1997; 30[8]:585-591.

(126) Aranishi, F., Ogata, H., Hara, K., Osatomi, K., and Ishihara, T., Susceptibility of opioid peptides and myofibrillar proteins to carp cathepsin L. J. Agric. Food Chem., 1998; 46[2]:388-392.

(127) Jiang, S.-T., Lee, J.-J., and Chen, H.-C., Proteolysis of actomyosin by cathepsins B, L, L-like, and X from mackerel (Scomber australasicus). J. Agric. Food Chem., 1996; 
44:769-773.

(128) Ogata, H., Aranishi, F., Hara, K., Osatomi, K., and Ishihara, T., Proteolytic degradation of myofibrillar components by carp cathepsin L. J. Sci. Food Agric., 1998; 76: 499-504.

(129) Purintrapiban, J., Wang, M., and Forsberg, N., Identification of glycogen phosphorylase and creatine kinase as calpain substrates in skeletal muscle. Int. J. Biochel. Cell Biol., 2001; 33[5]:531-540.

(130) Ladrat, C., Verrez-Bagnis, V., Noël, J., Fleurence, J., In vitro proteolysis of myofibrillar and sarcoplasmic proteins of white muscle of sea bass (Dicentrarchus labrax L.) : effects of cathepsins B, D and L. Food Chem., 2003; 81:517-525.

(131) Hochachka, P.W. and Brill, R. W., Autocatalytic pathways to cell death : a new analysis of the tuna burn problem. Fish Physiol. Biochem., 1987; 4:81-87.

(132) Kubota, M., Kinoshita, M., Kubota, S., Yamashita, M., Toyohara, H., and Sakaguchi, M., Possible implication of metalloproteinases in post-mortem tenderization of fish muscle. Fisheries Sci., 2001; 67[5]:965-968.

(133) Hallett, I. C. and Bremner, H. A., Fine structure of the myocommata-muscle fibre junction in hoki (Macruronus novaezelandiae). J. Sci. Food Agric., 1988; 44:245-261.

(134) Kubota, M. , Kinoshita, M., Takeuchi, K., Kubota, S., Toyohara, H., and Sakaguchi, M., Solubilization of type I collagen from fish muscle connective tissue by matrix metalloproteinase-9 at chilled temperature. Fisheries Sci., 2003; 69[5]:1053-1059.

(135) Lødemel, J. and Olsen, R., Gelatinolytic activities in muscle of Atlantic cod (Gadus morhua), spotted wolffish (Anarhichas minor) and Atlantic salmon (Salmo salar). J. Sci. Food. Agric., 2003; 83:1031-1036.

(136) Sentandreu, M. A., Coulis, G., and Ouali, A., Role of muscle endopeptidases and their inhibitors in meat tenderness. Trends Food Sci. Technol., 2002; 13:398-419.

(137) Delbarre-Ladrat, C., Verrez-Bagnis, V., Noël, J., and Fleurence, J., Relative contribution of calpain and cathepsins to protein degradation in muscle of sea bass (Dicentrarchus labrax L). Food Chem., 2004; 88:389-395.

(138) Olafsdottir, G., Martinsdottir, E., Oehlenschläger, J., Dalgaard, P., Jensen, B., Undeland, I., Mackie, I. M., Henehan, G., Nielsen, J., and Nilsen, H., Methods to evaluate fish freshness in research and industry. Trends Food Sci. Technol., 1997; 8:258-265.

(139) Sikorski, Z. E., In: Sikorski, Z.E. Ed., Seafood : Resources, Nutritional Composition, and Preservation. CRC Press, 1990; 231 p.

(140) Bremner, H. and Sakaguchi, M., A critical look at whether "freshness" can be determined. J. Aquatic Food Prod. Technol., 2000; 9[3]:5-25.

(141) Simeonidou, S., Govaris, A., and Vareltzis, K., Quality assessment of seven Mediterranean fish species during storage on ice. Food Res. Int., 1998; 30[7]:479-484. 
(142) Saito, T., Arai, K., and Matuyoshi, M., A new method for estimating the freshness of fish . Bull. Japan. Soc. Scient. Fisheries. 1959, 25, 749-750.

(143) Lakshmanam, P. T. and Gopakumar, P., K value, an index for estimating fish freshness and quality. Curr. Sci., 1999; 76[3]:400-404.

(144) Poli, B. M., Geri, G., Mascini, M., Parisi, G., Mecatti, M., and Guidotti, P., Estimate of post mortem loss of fish frshness with a biosensor system in rainbow trout (Oncorhynchus mykiss) and sea bass (Dicentrarchus labrax) at different storage temperature. Froid et Aquaculture, 1996; 357-362.

(145) Duflos, G., Dervin, C., Malle, P., and Bouquelet, S., Use of biogenic amines to evaluate spoilage in plaice (Pleuronectes platessa) and whiting (Merlangus merlangus). J. AOAC Int., 1999; 82[6]:1357-1363.

(146) Undeland, I., Lipid oxidation in fish - causes, changes and measurements. In: Olafsdottir, G., Luten, J., Dalgaard, P., Careche, M. Verrez-Bagnis, V., Martinsdottir, E., Heia, K., Eds, Methods to determine the freshness of fish in research and industry. Proceedings of the Final Meeting of the Concerted Action "Evaluation of Fish Freshness" AIRCT94 2283. Nantes. International Institute of Refrigeration, 1997; 241257.

(147) Gibson, D., and Ogden, I., Total viable counts. In: Olafsdottir, G., Luten, J., Dalgaard, P., Careche, M. Verrez-Bagnis, V., Martinsdottir, E., Heia, K., Eds, Methods to determine the freshness of fish in research and industry. Proceedings of the Final Meeting of the Concerted Action "Evaluation of Fish Freshness" AIRCT94 2283. Nantes. International Institute of Refrigeration, 1997; 147-150.

(148) Ogden, I., and Meyer, C., Rapid and differential methods in fish microbiology. In: Olafsdottir, G., Luten, J., Dalgaard, P., Careche, M. Verrez-Bagnis, V., Martinsdottir, E., Heia, K., Eds, Methods to determine the freshness of fish in research and industry. Proceedings of the Final Meeting of the Concerted Action "Evaluation of Fish Freshness" AIRCT94 2283. Nantes. International Institute of Refrigeration, 1997; 151157.

(149) Olafsdottir, G., Nesvadba, P., Di Natale, C., Careche, M., Oehlenschläger, J., Tryggvadottir, S., Schubring, R., Kroeger, M., Heia, K., Esaiassen, M., Macagnano, A. and Jorgensen, B., Multisensor for fish quality determination. Trends Food Sci. Technol., 2004; 15:86-93.

(150) Kyrana, V. and Lougovois, V., Sensory, chemical and microbiological assessment of farm-raised European sea bass (Dicentrarchus labrax) stored in melting ice. Int. J. Food Sci. Technol., 2002; 37:319-328.

(151) Touhata, K., Tanaka, M., Toyohara, H., Tanaka, H., and Sakaguchi, M., Seasonal change in collagen content of red seabream muscle. Fisheries Sci., 2000; 66[3]:553557.

(152) Thakur, D., Morioka K. I. Y., and Obatake, A., Influence of muscle biochemical constituents on the meat texture of cultured yellowtail (Seriola quinqueradiata) at different anatomical locations. J. Sci. Food. Agric., 2002; 82: 1541-1550. 
(153) Bugeon, J., Lefevre, F., and Fauconneau, B., Fillet texture and muscle structure in brown trout (Salmo trutta) subjected to long-term exercise. Aquaculture Res., 2003; 34:1287-1295.

(154) Gil, M., Hortos, M., and Sarraga, C., Calpain and cathepsin activities, and protein extractability during ageing of longissimus porcine muscle from normal and IPSE meat. Food Chem., 1998; 63[3]:385-390.

(155) Toyohara, H., Ando, M., and Shimizu, Y., Appearance of a 38,000-dalton component possibly associated with post-mortem tenderization of rainbow trout muscle. Agric. Biol. Chem., 1990; 54[6]:1575-1576.

(156) Bonnal, C., Raynaud, F., Astier, C., Lebart, M., Marcilhac, A., Coves, D., Corraze, G., Gelineau, A., Fleurence, T., Roustan, C., and Benyamin, Y., Postmortem degradation of white fish skeletal muscle (Sea bass, Dicentrarchus labrax): Fat diet effects on in situ dystrophin proteolysis during the prerigor stage . Mar. Biotechnol., 2001; 3[2]:172-180 .

(157) Delbarre-Ladrat, C., Verrez-Bagnis, V., Noel, J., and Fleurence, J., Proteolytic potential in white muscle of sea bass (Dicentrarchus labrax L.) during post mortem storage on ice: time-dependent changes in the activity of the components of the calpain system. Food Chem., 2004; 84[3]:441-446.

(158) Campbell, K., Three muscular dystrophies: loss of cytoskeleton - extramatrix linkage. Cell, 1995; 80:675-678.

(159) Trinick, J., Titin and nebulin : protein rulers in muscle ? TIBS, 1994; 19: 405-409. 